\title{
The Effects Of Using Collaborative Learning To Enhance Students' English Speaking Achievement
}

Fasawang Pattanpichet, Bangkok University, Thailand ${ }^{1}$

\begin{abstract}
This experimental study aims to investigate the effects of using collaborative learning to enhance students' speaking achievement. The study using a pre-test and post-test design was conducted with 35 undergraduate students enrolled in a fundamental English course at Bangkok University to examine their speaking achievement on an English oral test before and after they had participated in provided instructional tasks based on collaborative learning. To explore the students' views on the use of the collaborative learning, all of the students were asked to complete a student diary after finishing each task, fill in a four scale-rating questionnaire and join a semistructured interview at the end of the course. The data was analyzed by frequency, means, standard deviation, $t$-test, effect size (Hedge's g) and content analysis. The findings reveal the improvement of the students' speaking performance and positive feedback from the students on the use of collaborative learning activities. The study provides some pedagogical implications and suggestions for further investigations.
\end{abstract}

Keywords: Collaborative Learning; English Speaking Skills

\section{INTRODUCTION}

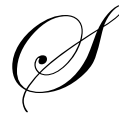

peaking skills are an essential part of second language learning and teaching (Kayi, 2006). Especially in Thailand, people are realizing the necessity of English speaking competence as the country is starting to take more roles in international community (Van De Bogart, 2009). However, Thai students have been struggling to acquire English speaking skills due to several reasons such as limited exposure to the language (Wiriyachitra, 2003), lack of the opportunities to practice, the native language interferences, lack of confidence, including English pronunciation of their Thai teachers ( Khamkhien, 2010). Moreover, speaking activities aiming to promote oral proficiency are sometimes perceived as face-threatening and nerve-wracking activities for Thai students. These negative feelings can deteriorate performance and affect students' self-esteem and confidence. Challenges in learning to acquire English speaking skills have led to a large volume of studies and articles focusing on providing effective instructional methods to help the students enhance their speaking skills (Pattaranon, 1988; Jong-Utsah, 1988; Van De Bogart, 2009; Songsiri, 2007; Pattanapichet, 2009; Janudom \& Wasanasomsithi, 2009; Khamkhien, 2010)

The importance of collaborative learning has long been emphasized and recognized as it is one method that can establish a comfortable and low-threat learning environment in the second language classroom. It is widely believed that the less anxious and more relaxed the learner is, the better his language acquisition proceeds. Moreover, many scholars have supported the effectiveness of the method in terms of learning achievement and learners' satisfaction. Collaborative learning is a concept derived from Vygotsky's social constructivism. According to Smith and MacGregor (1992), it is an umbrella term for a variety of approaches in education involving joint intellectual effort by students or students and teachers. It involves "a sense of the social nature of learning and the emphasis on a social approach to the development of learning skills, work skills and life skills" (Ingleton et al,

\footnotetext{
${ }^{1}$ Funding Acknowledgement: This study was supported by Bangkok University
} 
2004:3). It is an educational approach to teaching and learning that involves groups of learners working together to solve a problem, complete a task, or create a product. Allowing students to work together to maximize their own and others' learning is its goal. Collaborative learning is based on the idea that learning is a naturally social act in which the participants talk among themselves. It is through the talk that learning occurs. Collaborative learning strategies also offer promising possibilities for promoting active learning and student-reliance in community college classrooms (Foote, 2009). Oxford (1997: 443) states that collaborative learning is a reacculturative process which supports learners to become members of the knowledge communities whose common property is different from the common property of knowledge communities they already belong to. Wiener (1986) adds a different point of view focusing on the relationship between members in a group. He (1986:5) states that collaborative learning is dependent on the positive interdependence of group members, which provides the achievement of a common goal. Specially, students put into groups are only students grouped and are not collaborators, unless a task that demands consensual learning unifies the group activity. Thus, teachers must foster positive attitudes in group members that will result in interactive and productive group learning.

According to Gross (1993), students learn best when they are actively involved in the process. Many studies have reported that, regardless of the subject matter, students working in small groups tend to learn more of what is taught and retain it longer than when the same content is presented in other instructional formats. AshtonHay and Pillay (2010) also insert that collaborative learning can be used to provide a more inclusive and dynamic education for diverse learners. It can generate significant outcomes and benefits which resonate with the real world. Furthermore, in terms of learners' attitudes, students who work in collaborative groups also appear more satisfied with their classes (Beckman, 1990; Chickering and Gamson, 1991; Collier, 1980; Cooper and Associates, 1990; Goodsell, Maher, Tinto, and Associates, 1992; Johnson and Johnson, 1989; Johnson, Johnson, and Smith, 1991; Kohn, 1986; McKeachie, Pintrich, Lin, and Smith, 1986; Slavin, 1980, 1983; Whitman, 1988).

Nevertheless, despite the fact that many studies have indicated benefits and success in using this method of learning in second language classrooms, studies focusing on the use of the method in an English speaking classroom seem to be marginalized. Therefore, this study aims to investigate the effects of using collaborative learning in an English speaking classroom on both cognitive and affective aspects. The research questions are as follows.

1. What are the effects of using collaborative learning on the students' speaking achievement?

2. What are the students' views on collaborative learning after providing collaborative learning intervention?

\section{RESEARCH METHODOLOGY}

\section{The Participants}

The participants of the study consisted of thirty-five undergraduate students at Bangkok University.

\section{Research Instruments}

This study used five research instruments as listed below:
a. An oral test with a scoring rubric
b. Scoring sheets
c. A questionnaire asking the students' views on collaborative learning taken from Brown (2008).
d. A student's diary
e. A semi-structured interview

The English oral test was used to measure the participants' English speaking performance. The test consisted of three tasks: talking about oneself, having a telephone conversation and expressing one's opinions about a particular topic in public. The test was criterion-referenced aiming to measure the students' English oral performance on the scoring rubric. The scoring rubric provided a measure of quality of performance on the basis of five criteria: communication, vocabulary \& expressions, grammar, pronunciation and content on a four-rating scale ranging from 4 meaning 'exemplary' to 1meaning 'limited'. The test was used as a pretest and a posttest 
administered before and after the collaborative learning intervention. To ensure the content validity of the test, the test including the scoring rubric was validated and evaluated by three experts. The experts were asked to validate and evaluate the test by completing a checklist for the experts to validate the English oral test. The criteria on the checklist were taken from 'Criteria for assessment instruments of oral communication' available online at the website of National Communication Association (NCA). The results of the experts' evaluation of the test and the scoring rubric showed that all of the criteria used to assess the test received at least $\geq 3.50$ on the five-scale indicating positive opinions of the experts.

Students were asked to perform the three speaking tasks (one at a time) as part of each unit lesson. For each lesson, the language inputs such as a class discussion, reading and listening material and language patterns were given to the students. Then, they were assigned to take the pre-test the following week. After taking the pretest, they received the collaborative intervention by which they were involved in several pair or group activities done as either in-class or homework assignments. Then, they were assigned to take the posttest the following week. To ensure reliability of the scoring, two teachers evaluated each of the students' performance using the scoring sheet.

After finishing the posttest of each unit, the students were asked to fill in the student's diary to record their feedback toward the collaborative assignments. At the end of the course, the questionnaire to examine the use of collaborative learning was distributed to the students. The questionnaire was taken from Brown's (2008) questionnaire about collaborative learning using a four-rating scale ranging from strongly agree (4), agree (3), disagree (2) and strongly disagree (1). The questionnaire consisted of 20 items asking the students to indicate their opinions toward the use of collaborative learning. In the end, the semi-structured interview was used for clarification. All of the instruments had been validated by three experts in the field and had been piloted before the actual use. The questionnaire had been piloted with 30 students and calculated for proper reliability value by Cronbach's alpha coefficient. The reliability value of the overall questionnaire was 0.88 .

\section{DATA COLLECTION AND ANALYSIS}

Both quantitative and qualitative data was collected to examine the use of collaborative learning. Quantitative data was obtained from the oral performance tests and the questionnaire survey. All of the participants were asked to take the oral test before and after the course. Then, the results of the scores from t-test were used to indicate if participants in the study had higher scores in their oral post-test at a significant level $(p<.05)$. Next, the gained scores of the pre-test were calculated to find the effect size (Hedges' g). According to Cohen (1988), the values of the effect-size are used for the interpretation in terms of the correlation between an effect (collaborative learning) and the dependent variable (in the study - participants' oral achievement). Different people offer different advice regarding how to interpret the resultant effect-size, but the most accepted opinion is that of Cohen (1992: 155-159) where 0.2, 0.5, 0.8 is indicative of a small , a medium and a large effect respectively. In the study, the formula used to calculate the effect size is Hedges' effect size(g) since it is recommended by Barnette (2006) as the best choice for the same groups like pre-test, post-test design. At the end of the course, the participants were also asked to complete the questionnaire asking their feedback on collaborative learning. The results from the questionnaire were analyzed using SPSS program with percentile. Qualitative data was collected via the students' diaries and semi-structured interview for additional insights into the study. All of the participants were asked to fill the diaries after they completed each of the assignment tasks and they were asked to participate in the interview at the end of the course. The interviewer was a research assistant who was hired to conduct this interview. This allowed the participants to answer the interview questions freely without the presence of the researcher who was also the teacher of the course. Data from the interview was transcribed and analyzed using content analysis for additional insights into the study.

\section{RESEARCH FINDINGS}

Research question 1: What are the effects of using collaborative learning on the students' speaking achievement?

Participants were pre-and post-tested on their English speaking performance. Two raters rated each participant using the four scales on the scoring sheets. In this study, correlations of raters in the English oral pre- and post-test using Pearson Correlation were 0.96 and 0.84 respectively. The correlation is significant at the 0.01 level. 
In terms of raters' reliability, high correlations $( \pm 0.75)$ among raters have been found from both the pre-test and post-test. This indicates the degree to which the ratings of one rater can be predicted from the ratings of the other raters (Hatch and Farhady, 1982, p 203).

For statistical measurements, two scores given to each task from both raters were combined and divided by two to find out the mean scores for each of the participants. The results from t-test are presented in Tables 1,2 , and 3.

Table 1: The Oral Test (Task 1) - Paired Samples Test (T-Test) And Effect Size (Hedges' g)

\begin{tabular}{|c|c|c|c|c|c|c|c|}
\hline \multirow{2}{*}{$\begin{array}{l}\text { Talking } \\
\text { About } \\
\text { Oneself }\end{array}$} & \multirow[b]{2}{*}{ Min } & \multirow[b]{2}{*}{$\operatorname{Max}$} & \multicolumn{5}{|c|}{ Paired Differences } \\
\hline & & & $\mathrm{X}$ & SD & t-test & Sig (2-tailed) & G \\
\hline Pretest & 2.00 & 3.00 & 2.62 & 0.49 & \multirow{2}{*}{$10.49 *$} & \multirow{2}{*}{0.00} & \multirow{2}{*}{2.36} \\
\hline Posttest & 3.00 & 4.00 & 3.71 & 0.45 & & & \\
\hline
\end{tabular}

$* \mathrm{p}<0.05$

Table 2: The Oral Test (Task 2) - Paired Samples Test (T-Test) And Effect Size (Hedges' g)

\begin{tabular}{|c|c|c|c|c|c|c|c|}
\hline \multirow{2}{*}{$\begin{array}{l}\text { Having A } \\
\text { Telephone } \\
\text { Conversation }\end{array}$} & \multirow[b]{2}{*}{ Min } & \multirow[b]{2}{*}{$\operatorname{Max}$} & \multicolumn{5}{|c|}{ Paired Differences } \\
\hline & & & $\bar{X}$ & SD & t-test & Sig (2-tailed) & G \\
\hline Pretest & 2.00 & 4.00 & 2.97 & 0.70 & \multirow{2}{*}{$5.12 *$} & \multirow{2}{*}{0.00} & \multirow{2}{*}{1.20} \\
\hline Posttest & 3.00 & 4.00 & 3.68 & 0.47 & & & \\
\hline
\end{tabular}

$* \mathrm{p}<0.05$

Table 3: The Oral Test (Task 3) - Paired Samples Test (T-Test) And Effect Size (Hedges' g)

\begin{tabular}{|l|c|c|c|c|c|c|c|}
\hline \multirow{2}{*}{$\begin{array}{l}\text { Expressing } \\
\text { Opinions In } \\
\text { Public }\end{array}$} & Min & Max & $\bar{X}$ & SD & t-test & Sig (2-tailed) & G \\
\cline { 2 - 8 } & 1.00 & 3.00 & 1.62 & 0.59 & $16.55^{*}$ & 0.00 & 2.76 \\
\hline Pretest & 2.00 & 4.00 & 3.00 & 3.00 & & 2.00 \\
\hline
\end{tabular}

$* \mathrm{p}<0.05$

From the above tables, the results from t-test indicated that participants in the study had higher scores in their oral post-test at a significant level $(p<.05)$. According, to Cohen $(1988: 22)$, the values of the effect- size were used for the interpretation in terms of the correlation between an effect (in the present study - the collaborative learning intervention) and the dependent variable (in the study - participants' improvements in their English speaking performance). It can be seen from the three tables that there was significant improvement in the participants' speaking achievement. (pre-test $\bar{X}=2.62,2.97,1.62$; post test $\bar{X}=3.71,3.68,3.00$ ) with the effect size for each task at 2.36, 1.20, 2.76, each of which was considered a large effect. It can be concluded that the results of the oral test signified that the collaborative learning intervention had a positive effect on students' English oral performance.

Research question 2: What are the students'views on collaborative learning?

At the end of the intervention, the students were asked to complete a questionnaire about their opinions toward the use of collaborative learning. The questionnaire was taken from Brown (2008). The students were asked to rate their opinions toward the use of collaborative learning on a four-rating scale from 1 (strongly disagree) to 4 (strongly agree). Table 4 shows the results of the students' responses. 
Table 4: Students' Views On Collaborative Learning

\begin{tabular}{|c|c|c|c|c|c|}
\hline Working In Pairs And Groups... & $\begin{array}{l}\text { Strongly } \\
\text { Agree }\end{array}$ & Agree & Disagree & $\begin{array}{l}\text { Strongly } \\
\text { Disagree }\end{array}$ & Meaning \\
\hline 1. helped understanding/comprehension & $\begin{array}{c}16 \\
(45.7 \%) \\
\end{array}$ & $\begin{array}{c}15 \\
(42.9 \%) \\
\end{array}$ & $\begin{array}{c}3 \\
(8.6 \%) \\
\end{array}$ & $\begin{array}{c}1 \\
(2.9 \%) \\
\end{array}$ & Agree \\
\hline $\begin{array}{l}\text { 2. fostered exchange of knowledge, information and } \\
\text { experience }\end{array}$ & $\begin{array}{c}21 \\
(60 \%)\end{array}$ & $\begin{array}{c}13 \\
(37.1 \%)\end{array}$ & $\begin{array}{c}1 \\
(2.9 \%)\end{array}$ & $\begin{array}{c}0 \\
(0 \%)\end{array}$ & Agree \\
\hline 3. made problem-solving easier & $\begin{array}{c}20 \\
(57.1 \%)\end{array}$ & $\begin{array}{c}11 \\
(31.4 \%)\end{array}$ & $\begin{array}{c}3 \\
(8.6 \%)\end{array}$ & $\begin{array}{c}1 \\
(2.9 \%)\end{array}$ & Agree \\
\hline 4. stimulated critical thinking & $\begin{array}{c}20 \\
(57.1 \%) \\
\end{array}$ & $\begin{array}{c}13 \\
(37.1 \%) \\
\end{array}$ & $\begin{array}{c}2 \\
(5.7 \%) \\
\end{array}$ & $\begin{array}{c}0 \\
(0 \%) \\
\end{array}$ & Agree \\
\hline 5. provided more relaxed atmosphere & $\begin{array}{c}21 \\
(60.0 \%)\end{array}$ & $\begin{array}{c}13 \\
(37.1 \%) \\
\end{array}$ & $\begin{array}{c}1 \\
(2.9 \%)\end{array}$ & $\begin{array}{c}0 \\
(0 \%) \\
\end{array}$ & Agree \\
\hline 6. received useful/helpful feedback & $\begin{array}{c}23 \\
(65.7 \%) \\
\end{array}$ & $\begin{array}{c}9 \\
(25.7 \%) \\
\end{array}$ & $\begin{array}{c}2 \\
(5.7 \%) \\
\end{array}$ & $\begin{array}{c}1 \\
(2.9 \%) \\
\end{array}$ & Agree \\
\hline 7. got fresh insights & $\begin{array}{c}22 \\
(62.9 \%) \\
\end{array}$ & $\begin{array}{c}11 \\
(31.4 \%) \\
\end{array}$ & $\begin{array}{c}2 \\
(5.7 \%) \\
\end{array}$ & $\begin{array}{c}0 \\
(0 \%) \\
\end{array}$ & Agree \\
\hline 8. focused on collective efforts rather than individual effort & $\begin{array}{c}28 \\
(80 \%) \\
\end{array}$ & $\begin{array}{c}6 \\
(17.1 \%) \\
\end{array}$ & $\begin{array}{c}1 \\
(2.9 \%) \\
\end{array}$ & $\begin{array}{c}0 \\
(0 \%) \\
\end{array}$ & Agree \\
\hline 9. entailed greater responsibility - for myself and the group & $\begin{array}{c}18 \\
(51.4 \%) \\
\end{array}$ & $\begin{array}{c}16 \\
(45.7 \%) \\
\end{array}$ & $\begin{array}{c}1 \\
(2.9 \%) \\
\end{array}$ & $\begin{array}{c}0 \\
(0 \%) \\
\end{array}$ & Agree \\
\hline 10. enabled learners to help weaker learners in the group & $\begin{array}{c}22 \\
(62.9 \%) \\
\end{array}$ & $\begin{array}{c}11 \\
(31.4 \%) \\
\end{array}$ & $\begin{array}{c}1 \\
(2.9 \%) \\
\end{array}$ & $\begin{array}{c}1 \\
(2.9 \%) \\
\end{array}$ & Agree \\
\hline 11. enhanced communication skills & $\begin{array}{c}16 \\
(45.7 \%) \\
\end{array}$ & $\begin{array}{c}16 \\
(45.7 \%) \\
\end{array}$ & $\begin{array}{c}2 \\
(5.7 \%) \\
\end{array}$ & $\begin{array}{c}1 \\
(2.9 \%) \\
\end{array}$ & Agree \\
\hline 12. improved performance & $\begin{array}{c}19 \\
(54.3 \%) \\
\end{array}$ & $\begin{array}{c}15 \\
(42.9 \%) \\
\end{array}$ & $\begin{array}{c}1 \\
(2.9 \%) \\
\end{array}$ & $\begin{array}{c}0 \\
(0 \%) \\
\end{array}$ & Agree \\
\hline $\begin{array}{l}\text { 13. caused learners to actively participate in the } \\
\text { teaching/learning process }\end{array}$ & $\begin{array}{c}20 \\
(57.1 \%) \\
\end{array}$ & $\begin{array}{c}11 \\
(31.4 \%) \\
\end{array}$ & $\begin{array}{c}3 \\
(8.6 \%) \\
\end{array}$ & $\begin{array}{c}1 \\
(2.9 \%) \\
\end{array}$ & Agree \\
\hline 14. was fun & $\begin{array}{c}24 \\
(68.6 \%) \\
\end{array}$ & $\begin{array}{c}7 \\
(20 \%) \\
\end{array}$ & $\begin{array}{c}1 \\
(2.9 \%) \\
\end{array}$ & $\begin{array}{c}3 \\
(8.6 \%) \\
\end{array}$ & Agree \\
\hline 15. made new friends & $\begin{array}{c}19 \\
(54.3 \%) \\
\end{array}$ & $\begin{array}{c}14 \\
(40 \%) \\
\end{array}$ & $\begin{array}{c}1 \\
(2.9 \%) \\
\end{array}$ & $\begin{array}{c}1 \\
(2.9 \%) \\
\end{array}$ & Agree \\
\hline 16. fostered team spirit & $\begin{array}{c}24 \\
(68.9 \%) \\
\end{array}$ & $\begin{array}{c}8 \\
(22.9 \%) \\
\end{array}$ & $\begin{array}{c}2 \\
(5.7 \%) \\
\end{array}$ & $\begin{array}{c}1 \\
(2.9 \%) \\
\end{array}$ & Agree \\
\hline 17. was a waste of time regarding explaining things to others & $\begin{array}{c}11 \\
(31.4 \%) \\
\end{array}$ & $\begin{array}{c}7 \\
(20 \%) \\
\end{array}$ & $\begin{array}{c}6 \\
(17.1 \%) \\
\end{array}$ & $\begin{array}{c}11 \\
(31.4 \%) \\
\end{array}$ & Agree \\
\hline $\begin{array}{l}\text { 18. was difficult regarding getting members to actively } \\
\text { participate in tasks }\end{array}$ & $\begin{array}{c}11 \\
(31.4 \%)\end{array}$ & $\begin{array}{c}3 \\
(8.6 \%) \\
\end{array}$ & $\begin{array}{c}11 \\
(31.4 \%)\end{array}$ & $\begin{array}{c}10 \\
(28.6 \%)\end{array}$ & Disagree \\
\hline 19. (pair/group work) should be encouraged/continued & $\begin{array}{c}16 \\
(45.7 \%)\end{array}$ & $\begin{array}{c}11 \\
(31.4 \%)\end{array}$ & $\begin{array}{c}6 \\
(17.1 \%)\end{array}$ & $\begin{array}{c}2 \\
(5.7 \%)\end{array}$ & Agree \\
\hline 20. worked best when maximum group size was four & $\begin{array}{c}16 \\
(45.7 \%) \\
\end{array}$ & $\begin{array}{c}14 \\
(40 \%)\end{array}$ & $\begin{array}{c}3 \\
(8.6 \%) \\
\end{array}$ & $\begin{array}{c}2 \\
(5.7 \%)\end{array}$ & Agree \\
\hline
\end{tabular}

Table 4 revealed the students' views on collaborative learning. To analyze students' views on collaborative learning, the responses were merged into two categories: 'strongly agree' and 'agree' for 'agree' responses, and 'strongly disagree' and 'disagree' for 'disagree' responses. Each of the items was finally interpreted as either 'agree' or 'disagree' according to the majority of the responses. It can be seen that almost all of the items exhibit 'agree' responses except item no. 18, which shows disagree' responses. However, the figures show that 'disagree' responses outnumber 'agree' responses by only one response. A hair's breadth difference was also found in item no. 17. 'Agree' responses outnumber 'disagree' responses by only one response.

For clarity of analysis, Brown (2008) categorized the items in the questionnaire (as shown in Table 5) into four groups: academic benefits, social benefits, generic/life long learning skills and negative aspects of collaborative learning. Items no. 1,2,6,7,10,12,13 represent academic benefits; items no. 5,14,15 as social benefits; items no. 
$3,4,8,9,11,16$ as generic skills; and items no. 17, 18 represent negative aspects of collaborative learning. Items no 19 and 20 indicate additional comment.

Table 5: Percentage Combined Students' Responses By Categories

\begin{tabular}{|l|c|c|}
\hline \multicolumn{1}{|c|}{ Categories } & Agree & Disagree \\
\hline Academic benefits & $93 \%$ & $7 \%$ \\
\hline Social benefits & $93 \%$ & $7 \%$ \\
\hline Generic skills & $93 \%$ & $54 \%$ \\
\hline Negative aspects & $46 \%$ & $3 \%$ \\
\hline Continuing using collaborative learning & $77 \%$ & $14 \%$ \\
\hline Four people per group (max) & $86 \%$ & \\
\hline
\end{tabular}

From Table 5, it can be seen that the majority of the participants agree with all of the advantages accrued from collaborative learning. $93 \%$ of the students' responses are in agreement with all of the benefits of collaborative learning. Only $7 \%$ of the responses indicate disagreement. Nevertheless, regarding the two negative aspects, the percentage of the agreed responses and that of disagreed responses are pretty close. The results show 54\% agreement and $46 \%$ disagreement. It can be said that while the students agree with the benefits of collaborative learning, they also see that the method has some flaws regarding wasting time and the difficulty of getting members to actively participate in the tasks.

Moreover, since each of the students was required to complete and submit the student's diary after finishing each task, the expected total was 105 copies. In reality, only 99 pieces of the students' diaries were submitted. Some students failed to submit their diaries. Data from the students' diaries was analyzed using content analysis (coding, grouping and categorizing). Table 6 illustrates the findings from the students' diaries.

Table 6: Students' Diaries

\begin{tabular}{|l|c|}
\hline \multicolumn{1}{|c|}{ Students' Diaries } & Frequency \\
\hline What do you think about the assignment tasks? & \\
$-\quad$ I like it. & 97 \\
\hline I don't like it. & 2 \\
-Yes. & 93 \\
-No. & 2 \\
-Not sure. & 4 \\
\hline What have you gained from doing the assignment tasks with your partner/ teammates? (one diary possibly & \\
indicated more than one answer) & \\
-enjoyment, no stress, feeling active & 97 \\
-knowledge and better understanding & 78 \\
- useful feedback for improvement & 55 \\
-confidence & 35 \\
-encouragement & \\
-teamwork & 20 \\
\hline What were some obstacles you experienced when doing the assignment tasks with your partner/teammates? & 10 \\
-Wasting time & \\
-Difficult to get together after class & 9 \\
-Didn't receive cooperation or any contribution & 6 \\
-Nothing & 5 \\
\hline 5. What do you think about your progress after doing the assignment tasks? & 70 \\
-I think I improved a little. & \\
-I think I improved to a certain extent. & \\
-I think I improved a lot. & 25 \\
\hline
\end{tabular}


Table 6 presents the students' feedback on their diaries. More frequencies reveal positive feedback. The majority of the responses indicate the students' favor of the assignment tasks, the advantages of collaborative learning and the students' positive views on their improvement. Regarding the benefits the students gained from doing the tasks with their peers, six benefits were stated: enjoyment, better understanding, useful feedback, confidence, encouragement and teamwork. In terms of negative feedback, fewer frequencies were found. Three aspects: wasting time, difficulty in getting together after class, not receiving contribution were indicated as the obstacles in doing the assignments.

To ascertain these findings, a semi-structured interview was conducted with all of the participants. During the interview, the majority of the participants (33 students) indicated their favor of the use of collaborative learning. Some of their comments were:

"I liked the way the teacher allowed us to work in pairs and in groups. I enjoyed learning with my friends. I felt more relaxed"

'My friends helped me a lot. I practiced a lot with my friends and received useful feedback from them. That's why I was able to perform better'.

In addition, data from the interview provides some additional insights. Twenty-two students revealed that they helped one another monitor their progress and they felt more confident after they had practiced with their peers. Three students were skeptical about the method. They pinpointed that some characteristics of teammates were important factors affecting success or failure of the method. Some of their comments were:

'I can't say that the method is always appropriate and helpful. Sometimes it depends on whom you pair up or group with. For example, if I am in the same group with good students, I learned a lot from them, but if I am with weaker students, I sometimes felt that it was a waste of time'.

'It depends on whom you work with. Many times I had to work alone because I couldn't rely on any of my team members. Some were irresponsible. They didn't cooperate. Some couldn't provide any help because they didn't know how to. They were weak. So, I decided to work alone.'

\section{DISCUSSION}

The findings reveal positive outcomes both in terms of students' improvement on their English oral performance and their opinions toward the use of collaborative learning as an instructional method in an English speaking classroom. Based on the findings, it can be seen that the method can be of great use in developing the students' competence and creating positive learning atmosphere due to several reasons. First of all, fruitful collaboration among the students brings about a sense of unity and greater familiarity. Frequently working in collaboration with their peers, the students became more and more familiar with the tasks and one another. While their familiarity and friendship were growing, their anxiety and face threats were simultaneously lowering as the students' feedback revealed that they had no stress, felt relaxed and enjoyed themselves in class. Second, collaborative learning is an appropriate and effective instructional method for a large class. By arranging groupwork or pair-work activities, nobody in the class was left out. The teacher was able to lead a big class by having every student practice on their own with their partners or their teammates at the same time while the teacher was monitoring each group. This encouraged students to have responsibility for their own learning and at the same time created knowledge-sharing atmosphere. Moreover, the fact that collaborative learning helps create classroom atmosphere resembling real life social and employment situations in which students interact, negotiate and share ideas with one another is a good reason to implement this method. The method allows the students to have a lot of opportunities to practice within constraints of time. The students were able to practice with their peers outside classroom as much as they wanted. Apart from multiple practices that they were able to achieve, the students also learned how to work in a team. This helped develop social skills beneficial for them in the future. Last but not least, the students benefited from continuous self and peer assessment. For each task, the students were asked to assess their performance and their peers'. They needed to indicate their own strengths and weaknesses and give each other 
comments. This helped them learn to improve and perform better. It can thus be concluded that all of these factors have contributed to the success of the method.

As for negative aspects of the method, two issues: wasting time and difficulty in getting cooperation were pinpointed. Some suggestions would be as follows. First of all, it is very important for teachers to design appropriate collaborative activities. The tasks should have some structure or pattern and be simplified so that it is easy for everybody to understand their roles in doing the tasks. Then, time will not be wasted on giving directions on how to do the tasks and getting people to do the tasks. Also, teachers need to provide some guideline to help the students get started including ongoing close monitoring during the process. This allows the teachers to offer immediate assistance as soon as problems arise. Furthermore, this constant monitoring from the teacher can help ameliorate the free rider problem (also known as social loafing). On the watch of the teacher, the students will be more alert and tend to do their fair share of work on a group project. In addition, in this study asking the students to complete the diary on a regular basis was one way for the teacher to monitor the students' working. The student's dairy, apart from being used as a research instrument, was also used as a part of instructional instrument for the students to conduct a self and peer appraisal. The use of the student's diary was helpful to reduce free riding as it was one way of interactions between each of the team members and the teacher. Once the teacher was aware that the problem occurred, she was able to handle it immediately. This idea is in line with Brooks and Ammons (2003). They recommend that having multiple peer evaluations during the course of the project reduces social loafing. They (2003) also propose a group evaluation system that involves early implementation, assessments at multiple time points, and the use of specific criteria to help reduce free rider problems. Finally, it is very important for teachers to take the size and group composition as well as the scope of the project into careful consideration. Aggarwal and O' Brien (2008) find that the scope of the project and the size of the student group assigned to the project affect the increase of social loafing. Researchers have not identified a single ideal type of group composition. However, according the findings of this research, the students indicated groups of about four should be the maximum. Dillenbourg and Schneider (1993) indicate group composition as one factor that determines the efficiency of collaborative learning and this factor is defined by several variables: the age and levels of participants, the size of the group, the difference between group members, etc. They suggest that some 'optimal heterogeneity' such as some difference of viewpoints is required to trigger interactions, but within the boundaries of mutual interest and intelligibility.

\section{CONCLUSION}

The findings of the study support the use of collaborative learning in teaching English speaking. However, it is not the case that any way of doing it will be effective. Further studies can be done to investigate the effects of using collaborative learning with younger or older students to see if they would provide the same outcomes. Studies investigating some factors such as group characteristics can be illuminating as they can provide some additional insights on the use of the method.

\section{ACKNOWLEDGEMENT}

This study was supported by Bangkok University

\section{AUTHOR INFORMATION}

Dr. Fasawang Pattanapichet received her $\mathrm{PhD}$ in English and International Language from Chulalongkorn University in 2009, an M.A. in TESOL from Eastern Michigan University in 2002, and B.A. with Second-class Honors in English language and literature from Thammasat University in 1999. Dr. Fasawang has been working as a full-time faculty member of Language Institute, Bangkok University for seven years. Her fields of interest include English instruction, English for specific purposes and curriculum development. Dr. Fasawang Pattanpichet, Bangkok University, Rama 4 Road, Klong-Toey, Bangkok, Thailand 10110. E-mail: ajfasawang@gmail.com 


\section{REFERENCES}

1. Aggarwal, Praveen \& O'Brien, Connie (2008). Social loafing on group projects: structural antecedents and effects on student satisfaction. Journal of Marketing Education, 30(3), 255-264.

2. Ashton-Hay, Sally \& Pillay, Hitendra K. (2010). Case study of collaborative learning in two contexts : what do English language learners gain? In: Luzzatto, Edda \& DiMarco, Giordano (Eds.) Collaborative Learning: Methodology, Types of Interactions and Techniques. Education in a Competitive and Globalizing World. Nova Publishers, New York.

3. Barnette, J. (2006).Assessing Data Collection Instruments. Retrieved June 11,2011from http://www.eval.org/summerinstitute/06SIHandouts/SI06.Barnette.BO24.Online.pdf

4. Beckman, M. (1990). Collaborative Learning: Preparation for the Workplace and Democracy. College Teaching, 38(4), 128-133.

5. Brooks, Charles M. and Janice L. Ammons (2003), Free Riding in Group Projects and the Effects on Timing, Frequency, and Specificity of Criteria in Peer Assessments, Journal of Education for Business, 78 (5), 268-271.

6. Brown, F.A. (2008).Collaborative Learning in the EAP Classroom: Students' Perceptions. ESP World, 1(17). Retrieved April 20,2011from http://www.espworld.info/Articles 17/PDF/Collaborative\%201learning.pdf

7. Chickering, A. W. (1991). Applying the Seven Principles for Good Practice in Undergraduate Education. In Z. F. Gamson (eds.), New Directions for Teaching and Learning, no.47. San Francisco: Jossey Bass.

8. Cohen, J. (1988). Statistical power analysis for the behavioral sciences (2nd ed.). Hillsdale, NJ: Lawrence Earlbaum Associates.

9. Cohen, J. (1992). A power primer. Psychological Bulletin, 112, 155-159.

10. Collier, K. G. (1980). Peer-Group Learning in Higher Education: The Development of Higher-order Skills. Studies in Higher Education, 5(1), 55-62.

11. Cooper, J., and Associates. (1990). Cooperative Learning and College Instruction. California: Long Beach: Institute for Teaching and Learning, California State University.

12. Dellenbourg, P. and Schneider, D. (1993).Collaborative learning and the internet. US: TELFA (Unit of Educational Technology School of Psychology and Education).

13. Foote, E. (2009). Collaborative Learning in Community College [online] Retrieved April 20,2011from http://www.ericdigests.org /1998-1/ colleges.htm>.

14. Goodsell, A., Maher, M., Tinto, V, and Associates (1992). Collaborative Learning: A Sourcebook for Higher Education. Pennsylvania: University Park: National Center on Postsecondary Teaching, Learning, and Assessment, Pennsylvania State University.

15. Gross, B. (1993). Tools for Teaching. San Francisco: Jossey-Bass Publishers.

16. Hatch, E.and Farhady, H. (1982).Research design and statistics for applied linguistics. Rowley: Newbury House Publishers.

17. Ingleton, C., Doube, L., Rogers, T. and Noble, A. (2004). Leap into ... Collaborative Learning. Centre for Learning and Professional Development (CLPD).The University of Adelaide, Australia

18. Janudom, R. and Wasanasomsithi, P. (2009). Drama and questioning techniques: powerful tools for the enhancement of students' speaking abilities and positive attitudes towards EFL learning. ESP World 5(26).Retrieved April 20,2011from www.esp-world.info

19. Johnson, D.W., Johnson, R.T. and Smith, K.A. (1991) Cooperative Learning: Increasing College Faculty Instructional Productivity. ASHE-FRIC Higher Education Report No.4. Washington, D.C.: School of Education and Human Development, George Washington University.

20. Jong-Usah, K. (1988). A Level of English Speaking Ability of Students at the Lower Secondary Education Level. M.A. Thesis, Chulalongkorn University.

21. Kayi, H (2006). Teaching speaking: Activities to promote speaking in a second language. The Internet TESL Journal, 12 (11). Retrieved April 20,2011from http://iteslj.org/Techniques/Kayi-

TeachingSpeaking.html

22. Khamkien A. (2010) Teaching English speaking skills and English speaking tests in the Thai context: A reflection from Thai perspective. English Language Teaching, 3:184-190. 
23. McKeachie, W. J., Pintrich, P R., Lin, Y.-G., and Smith, D.A.F. (1986). Teaching and Learning in the College Classroom: A Review of the Research Literature. Ann Arbor: National Center for Research to Improve Postsecondary Teaching and Learning, University of Michigan.

24. Oxford, R. (1997). Cooperative Learning, Collaborative Learning, and Interaction: Three Communicative Strands in the Language Classroom. The Modern Language Journal, 81 (iv), 443-456.

25. Pattanapichet, F. (2009). A Development of Competency-based English Oral Communication Course for Undergraduate Public Relations Students. PhD Dissertation, Chulalongkorn University.

26. Pattaranon, S. 1988. A level of English speaking ability of students at the upper secondary education level. M.A. Thesis. Chulalongkorn University

27. Riwindiasih,S. (2009). Collaborative learning model in teaching speaking using role-play based on the school level based curriculum to the first year students of SMAN 1 SRAGEN in 2007/2008 Academic Year. B.Ed. Research Paper, Muhammadiyah University of Surakarta

28. Slavin, R. E. (1983). When Does Cooperative Learning Increase Student Achievement? Psychological Bulletin, 94(3), 429-445.

29. Smith, B.L., and MacGregor, J. T. (2009). What is collaborative learning? National Center on Postsecondary Teaching, Learning and Assessment at Pennsylvania State University [online] Retrieved April 3,2011 from <http://learningcommons.evergreen.edu/pdf/collab.pdf

30. Songsiri, M. (2007). An action research study of promoting students' confidence in speaking English. Other Degree thesis, Victoria University.

31. Van De Bogart, W. (2009). Developing a Pedagogy for Active Learning (PAL). Academic Journal, 4:146183.

32. Vygotsky, L. (1978). Mind in society: The developmental of higher psychological process. Cambridge, MA: Harvard University Press.

33. Whitman, N. A. (1988). Peer Teaching: To Teach Is to Learn Twice. Washington, D.C.: ASHE-ERIC Higher Education Report No.4. Washington, D.C.: Association for the Study of Higher Education.

34. Weiner, H.S. (1986). Collaborative learning in Classroom a Guide in Evaluation. College English 48(1):5261.

35. Williams, J.A. (2001) Classroom Conversations: Opportunities to learn for ESL Students in Mainstream Classroom. The Reading Teacher, 54 (8), 750-757

36. Wiriyachitra, A (2001) A Thai university English scenario in the coming decades. Thai TESOL Newsletter, 14: 4-7. 